\title{
Implemenation of FEM and Rapid Prototyping in Maxillofacial Surgery
}

M. Sljivic
Full Professor
University of Banja Luka
Faculty of Mechanical Engineering
Bosnia and Herzegovina
M. Stanojevic
Dr.
University of Banja Luka
Faculty of Mechanical Engineering
Bosnia and Herzegovina
D. Djurdjevic
Dr
University of Banja Luka
Faculty of Medicine
Bosnia and Herzegovina
N. Grujovic
Full Professor

A. Pavlovic

$\mathrm{PhD}$

Alma Mater University of Bologna, Department of Industrial Engineering

This paper investigates the opportunity of implementing FE simulations and rapid prototyping tecniques on titanium implant in maxillofacial surgery case based on osteotomy. Maxilla region was recorded by Cone Beam CT with high resolution and optimal radiation. Then, it followed the medical image reconstruction into $3 D$ voxelized model. This model was converted both, to stl surface model for rapid prototyping, CAD modeling and FE mesh for simulation purposes with keeping good volume and dimensional consistency. Stl meshed surface was imported into CAD software, as initial $3 d$ structure, which is used for parametric and customized design of implant. Since, the osteotomy is final application, it wassimulated the cutting and shifting of maxilla for proper correction by digital prototyping. Then, the fixation points for shifted maxilla were determined by surgeon to provide steady and tight joints between implanting screws and maxilla. Applied implant was given in initial standard flat configuration. Flat implant configuration was adapted by complex $3 D$ bending in CAD software to be customized towards surface conformity of maxillofacial anatomy. By FE simulation in MSC Patran/Nastran, it was performed the stress analysis of implant with different thickness configurations and $3 D$ bending, which provides the optimized implant model with best fit dimensions. Optimized implant model and corresponding body model were converted into physical models. RP model of maxilla was post-processed by cutting and boring to provide an adequate implant positioning according to digital prototypes. This approach facilitated the preparation of complex shaped implants in swept and lofted form, what had to be in high degree of conformity to anatomy surface. To approve a good practical opportunity, it was applied and tested in concrete surgery case of maxillofacial osteotomy.

Keywords: Cone Beam CT, Finite Element Method, Rapid Prototyping, Parametric Customization of Implants

\section{INTRODUCTION}

This paper aims at investigating a multidisciplinary approach, based on Finite Element Methods (FEM) and Rapid Prototyping (RP), for effective osteotomy surgery planning.

In the area of surgery planning, there are numerous research papers based on virtual or digital prototyping. Usually, the Virtual Prototyping (VP) is focused on the conversion from Dicom format to $3 \mathrm{D}$ voxel model of treated anatomical areas with simulated implantation and verification of proper size selection, positioning and direction of insertion. Generally, it includes a 2D and 3D filtering of observed volume data with keeping correct dimensions, removing of noise from computer tomography [1]. Beside every R\&D actions, VP is going to be very common clinical practice in surgery planning, as well. A typical approach based on virtual prototyping is presented in Figure 1.

Received: May 2016, Accepted: June 2016

Correspondence to: Prof. Milan Sljivic

Faculty of Mechanical Engineering in Banja Luka

Bulevar Stepe Stepanovica 75, Banja Luka, B\&H

E-mail: milan.sljivic@unibl.rs

doi:10.5937/fmet1604422S

(C) Faculty of Mechanical Engineering, Belgrade. All rights reserved

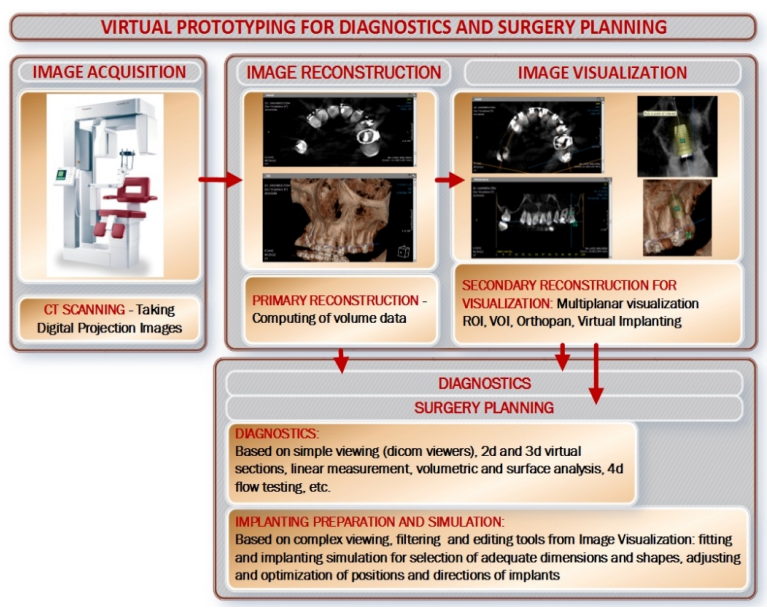

Figure 1: Standard approach of Virtual Prototyping for the purpose of diagnostics and surgery planning

As an initial stage, a 2D imaging is realized by CT, MRI or other image acquisition systems. Primarily, the reconstruction is related to a 2D Fourier Transformation and Radon Transform. From the initial acquisition, a 2D images is reconstructed in form of slices in z-direction. The raw set of images is usually converted into Dicom format. 
In common diagnostics practice, there are numerous Dicom viewers with some viewing options based on sections and filtering with range selection in Hounsfield units. It provides simple anatomy segmentation according to the material density and its adequate attenuation of radiation, like separation between bones and soft tissues etc. Also, it is possible to make simple dimensional measurements of anatomy sizes.

As a further advanced step, there is more sophisticated image processing with image filtering to remove undesirable noise, and many editing tools as automatic, semi-automatic and manual options.

The adoption of these tools usually requires experienced user, especially in the area of low image contrast like cone beam CT (CBCT) systems, and where there is a contact surface area of two anatomical bodies with similar density, as bones in the knee or hip/acetabulum area. It is also possible to make complex curved sections like orthopan.

As the combination of voxelized anatomy and parametric models of implants, there is an opportunity to make implant analysis in virtual/digital environment.

However, within this well-developed current flow of virtual prototyping, it is recognized the opportunity to apply the other engineering tools like rapid prototyping and FEM simulation. In this paper, it is shown the opportunity to make synergic implementation of these tools within osteotomy application of maxilla.

Specific case of maxilla is to have thin bone structures in some areas and low bone density, what causes low quality level voxelization, which should be reconstructed by image filtering and editing tools. At the same time, it is very important to keep high dimensional and volumetric stability for the further process flow steps.

In the next chapter, it is proposed a procedure, which includes rapid prototyping and FE analysis as combination surgery planning for osteotomy. In this case, a maxilla osteotomy was considered.

\section{METHODS AND PROPOSED PROCEDURE}

With aim to improve surgery planning of osteotomy with deformed titanium plates and its stress testing by FEA, the a specific procedure was developed. In the Figure 2, it is presented in term of the new workflow, which helps in selection of adequate thickness of implant plates and its final deformed geometry.

In brief, the proposed procedure is segmented into a few stage groups, as follows: pre-processing of $s t$. surface model from Dicom file recorded by Cone Beam CT, hybrid modelling as combination of stl. meshing, surface and solid cad parametric modelling, finite element analysis of loaded implant plates, Rapid Prototyping of the real mock up and finally, surgery planning based on adaptation of titanium plates which is deformed in accordance with tracing the $3 d$ curve along with RP external surface of maxilla.

Every methodological step will be analysed in full details with practical case on osteotomy of maxilla area.

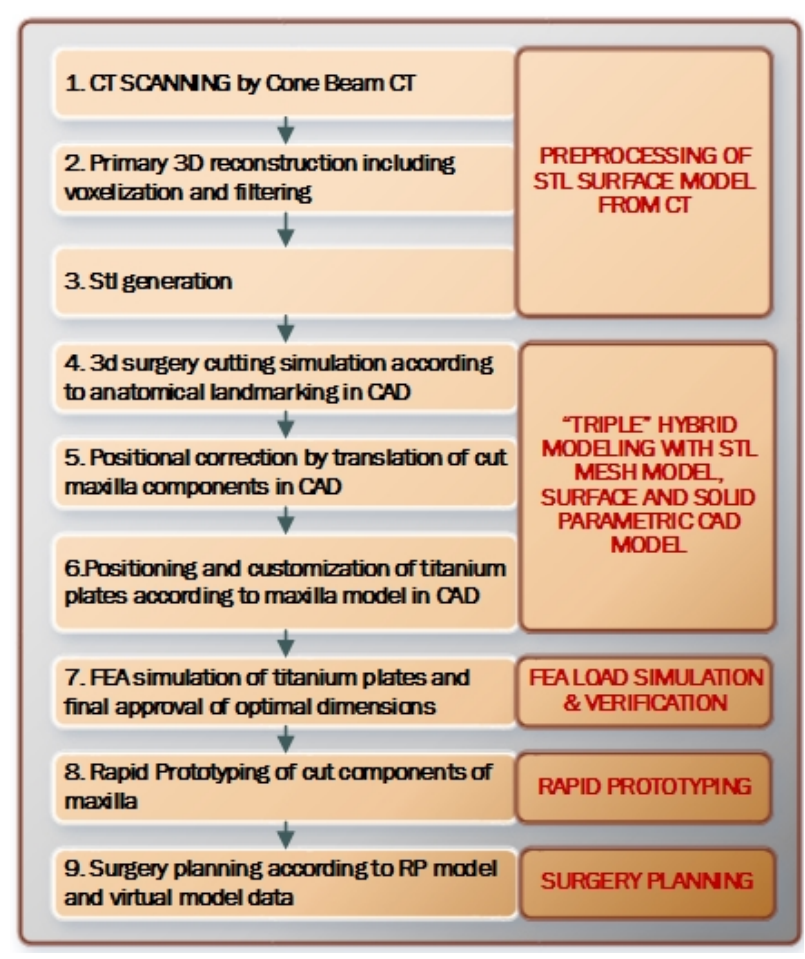

Figure 2: Standard approach of virtual prototyping for the purpose of diagnostics and surgery planning

\subsection{Pre-processing of stl. surface model from CT record}

CT recording was performed by Soredex CBCT system. Cone Beam technology is certain new with low radiation and useful for diagnostics and surgery planning in dentistry and maxillofacial surgery. There are some issues about contrast resolution and noise emanated by metal artefacts, but it is controllable with adequate combination of low pass image filtering, both in $2 d$ background image set and $3 d$ mask's level [2]. For Virtual Prototyping (Figure 1.), Soredex CT system was combined with OnDemand3D App, to make virtual 3D analysis and planning. Appropriate slice thickness for maxilla area is $0.6 \mathrm{~mm}$ or smaller. In this case study, it was $0.2 \mathrm{~mm}$ what requires longer time computing. However, it is recognized that for stl. meshing it is necessary to apply software like ScanIP by Simpleware (figure 3). This software is specialized for both image reconstruction and stl. surface meshing for medical and engineering purposes. They have robust algorithms for stl. meshing with keeping good volumetric data.

In the anatomical structures like maxilla, with thin bones in some areas and low image contrast, they were specially treated as localized region with proper lowpass filter's adjusting. Also, where there were few segmented components, like mandible and maxilla, they have been treated separately with generation of 3D models and their stl. meshing surfaces [3]. It enables the process of osteotomy simulation, where the mandible is with the fixed constraints. Also it was important to make proper mesh decimation, since it was used later in hybrid modelling with the keeping of high surface relief consistency. Depending on the size of examined maxilla area and its topology complexity, it was about 150000 to 300000 elements maxillofacial area. 


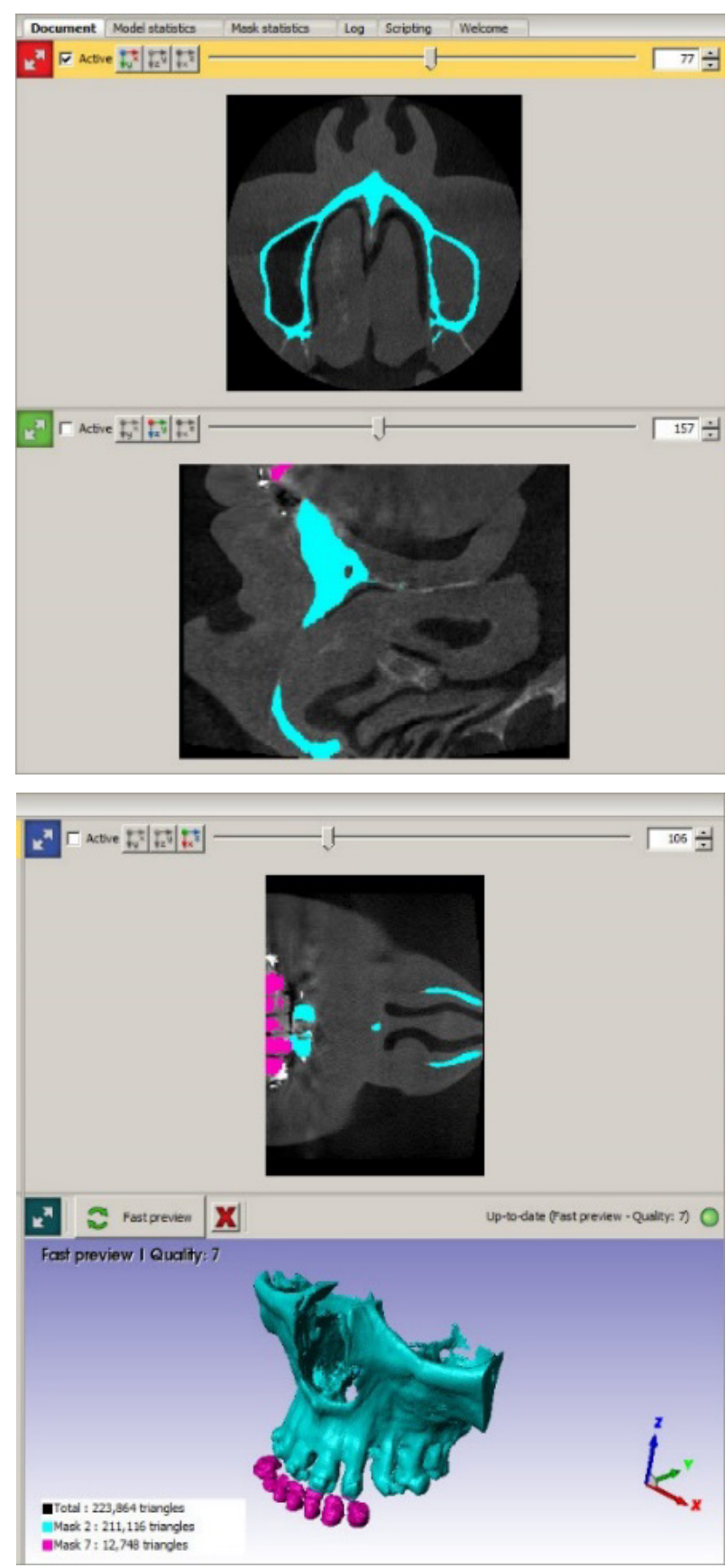

Figure 3: Image processing and filtering of Cone Beam CT scan by ScanIP - Simpleware

\subsection{Hybrid modelling with stl. mesh model and parametric CAD model}

After generation of appropriate stl. mesh model of maxilla, the next step was so called hybrid modelling as a combination of mesh $3 d$ interpretation, parametric surface and solid cad approach. Firstly, it was necessary to simulate cutting of maxilla with adequate parametric $3 d$ surface.

It generates more separated and open mesh groups, what requires the removing of certain mesh "islands" as unnecessary residue. Also, it is essential to close the meshes and to keep good definition of bone's geometry, what provides good definition of stl. files aimed for rapid prototyping (Figure 3 and 4) [4].

Figure 5 shows the cutting process and the editing of separated meshes. In some cases, when necessary, it was possible to add "technical stiffener" with easy recog- nition, what was anatomic/non-anatomic structure for surgery planning stage. It helped to keep proper distances and measurements between anatomic components. Adequate splitting tools provided the keeping clear anatomic surfaces.

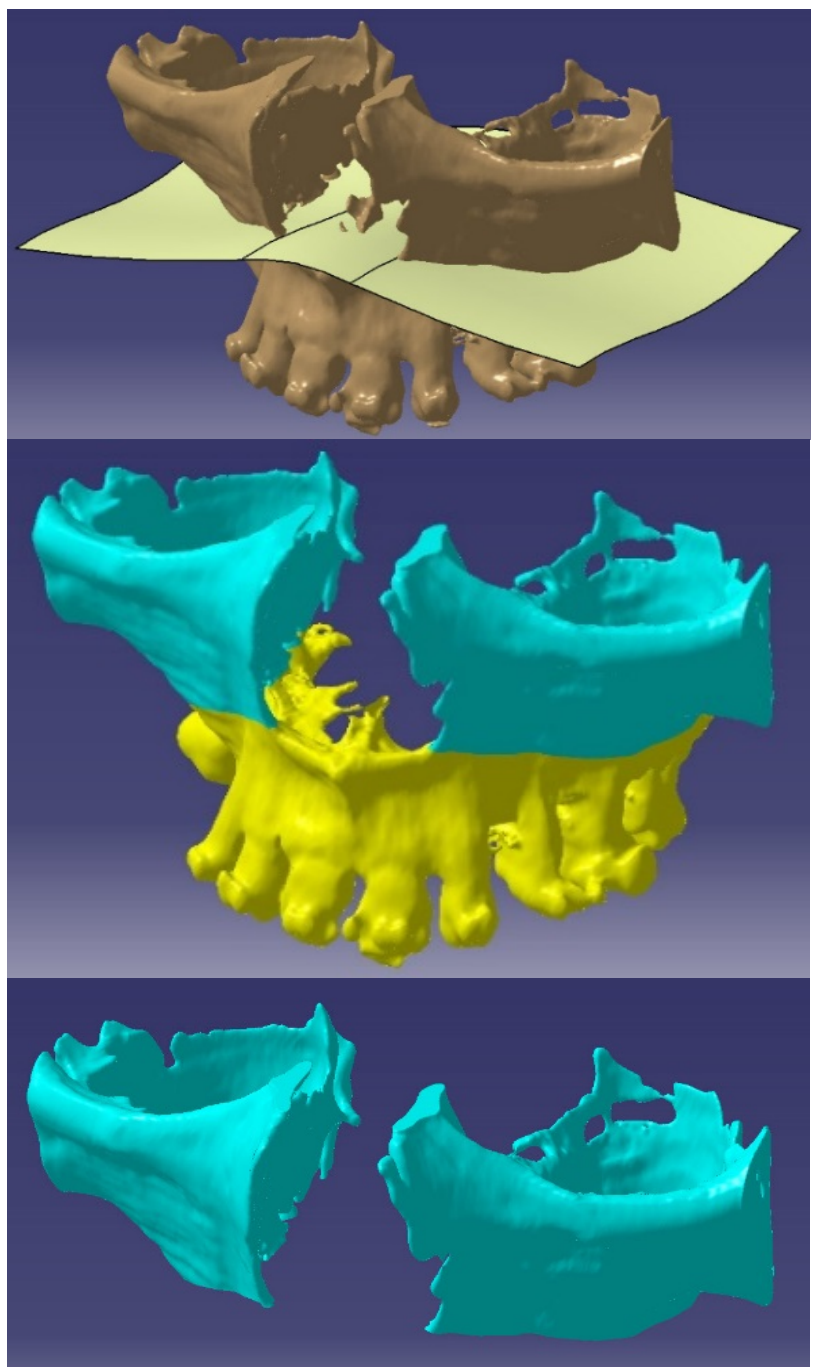

Figure 4: Stl. meshing of disassembled parts

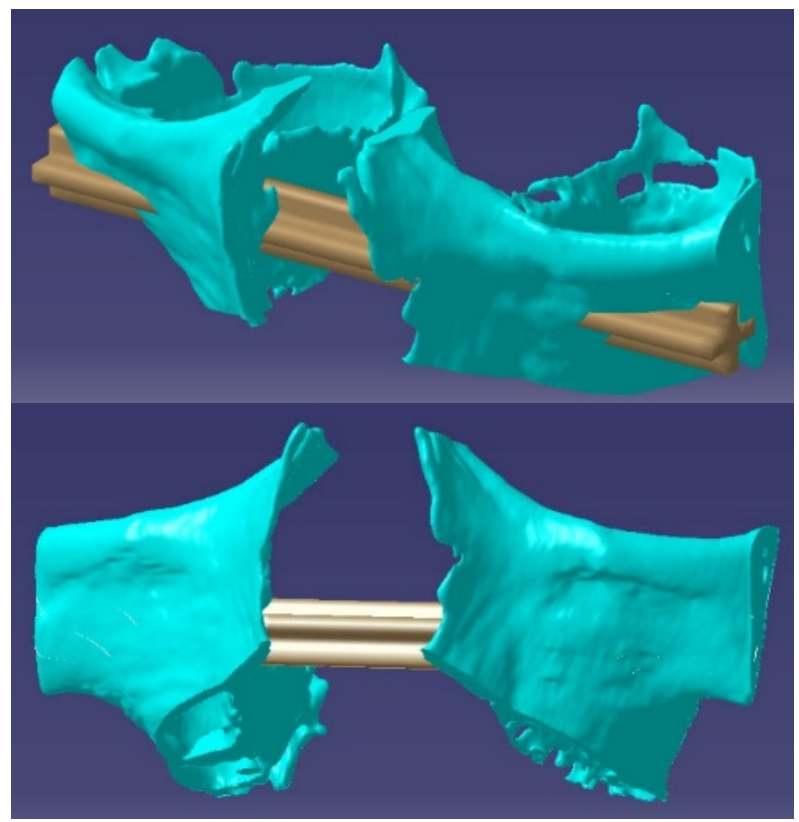

Figure 5: Modifying of stl surface model 
Since it was provided "the assembly approach" of maxilla, it was possible to translate some components between each other, separately, like in Figure 6, what helped to determine the dimension of translation and to fix new desirable position of movable part of maxilla.

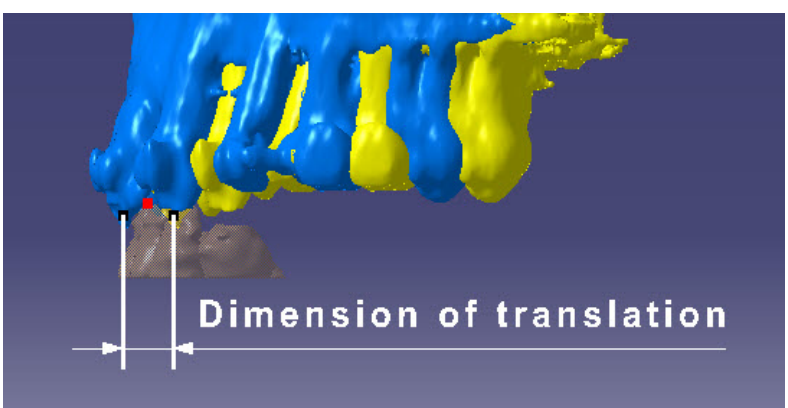

Figure 6: Digital prototyping of translated maxilla

After this step, hybrid modelling was included by implementation of parametric CAD modelling with provided interaction between mesh model and CAD model with editing opportunities. In this case study, parametric CAD model was titanium plate called MatrixCombo Plating System by Synthes. There were few dimensional and geometrical options. The proper dimension was selected by FE analysis as detailed in the followings. Interaction between mesh model of maxilla and titanium plates assisted to make the most suitable deformed form of plates. Before plate positioning on maxilla surface, the surgeon determined a positioning on virtual model (Fig. 3) and on a real model (Figure 8).
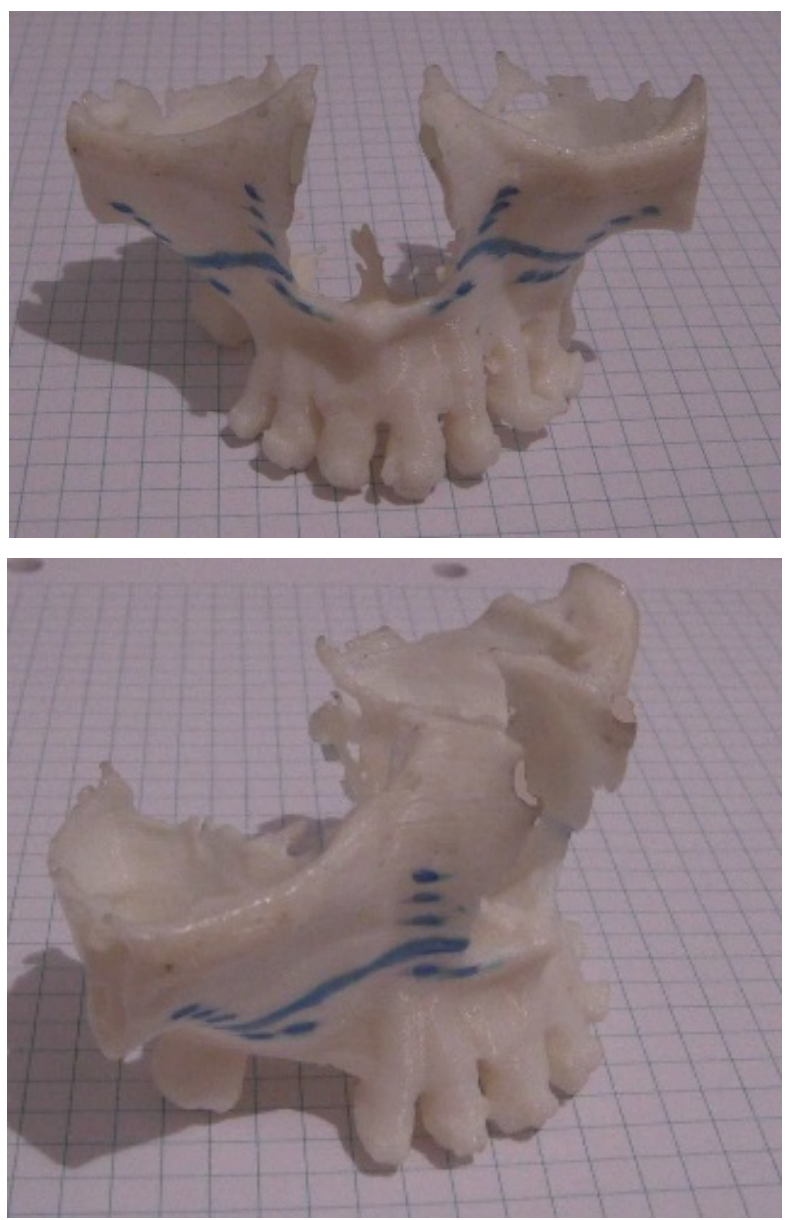

Figure 7: Plate locating by surgeon before their parametric modelling
To simplify the analysis, in this paper the screw load is neglected. It is supposed having robust fixing of titanium plates with including all screws in any available hole on deformed plates. In the future research, the complex screw load with interactions of nonlinear material model of bone's porous structure would be observed. At the end of this step, the model and deformed form of customized titanium plates are selected. In the next FEA stage, it will be analysed and verified the adequate size of plates according to critical stress on bending lines.
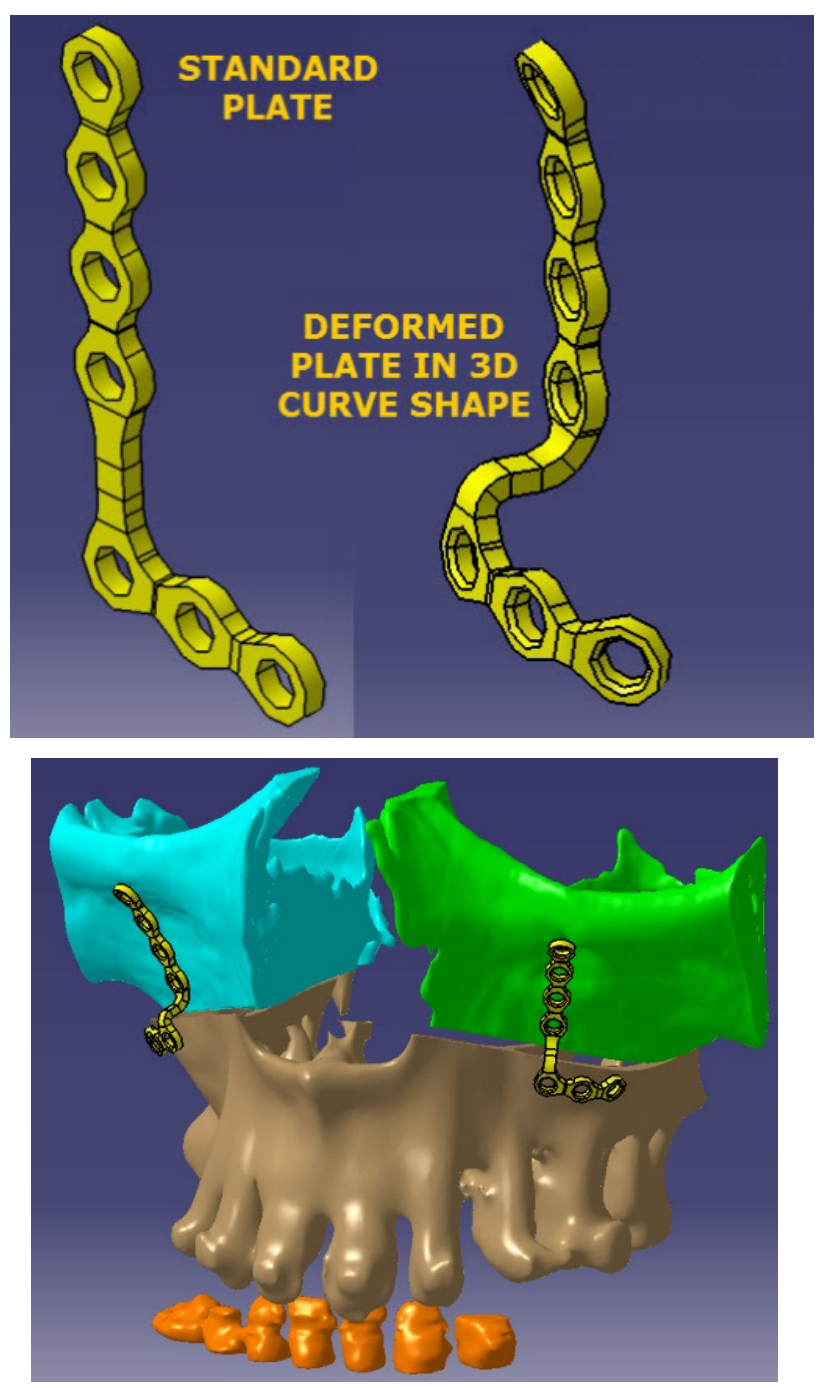

Figure 8: Titanium plate design in deformed shape for osteotomy surgery

\subsection{FEA load simulation and verification}

In order to make well designed FEA case, it is important to prepare realistic approximation of load conditions. In this case, it was simulated the resultant bite force with location by center of gravity on bite surface, with the most "pessimistic" load scenario, where the full load was concentrated on plates [5].

Since the resultant bite force had very similar distance as the reaction force of titanium plates related with temporomandibular joint (TMJ), it was assumed these forces had similar intensity, see figure 9. Also, it was assumed there was a symmetric distribution on left and right side of face. Total bite force was given as 
$120 \mathrm{~N}$, or $60 \mathrm{~N}$ for one side [6]. According to the abovementioned parameters, the load simulation was made for different plate thickness: $0.8 \mathrm{~mm} ; 1.0 \mathrm{~mm} ; 1.2 \mathrm{~mm}$. As the initial value, it was taken the standard geometry configuration with the biggest thickness $0,8 \mathrm{~mm}$ for the trauma surgery in mid-face region. Because, in osteotomy it is important to make certain larger distance or angle of cuts, it is often case to have more deformed shape of plates with complex load and stress distribution. So, it was supposed to increase thickness for additional configurations in 2 increments with $0.2 \mathrm{~mm}$

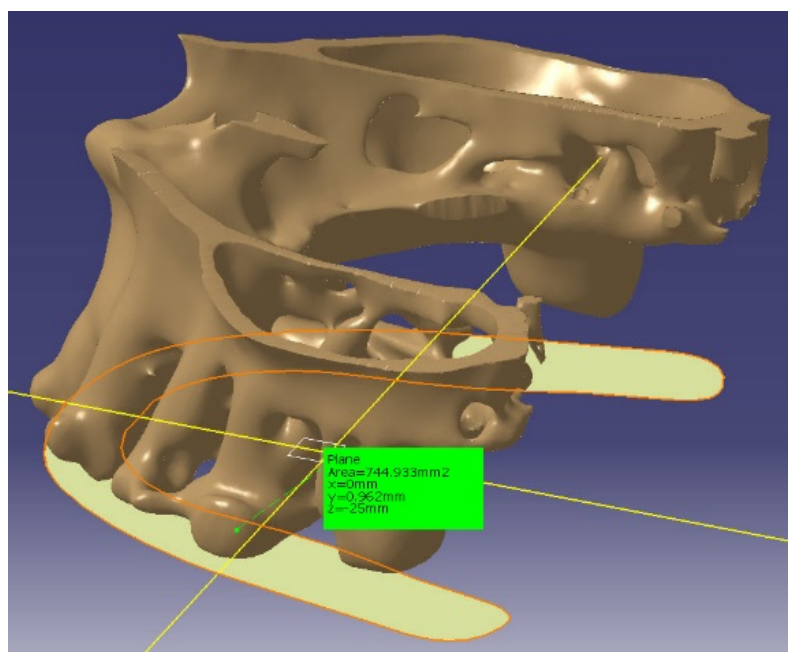

Figure 10: Calculation of the resultant bite force and its positioning

\subsection{Rapid prototyping and surgery planning}

After previous 3 steps, which could be called digital or virtual prototyping in technical sense, the following stage was the real (physical) prototyping, which directly assisted to surgery planning through the most realistic 3D overview, positioning of titanium plates and their preprocessing by deforming in accordance with external surface of RP model, which represents maxilla.

In this research, it was analysed the preparation on 2 very frequent standard options of rapid prototyping, FDM method by Stratasys and Multi-Jet Printing by 3D System. 3D surface meshing model generated in stl file was imported in adequate pre-processing software for rapid prototyping. In the case of multijet printing it was used 3D-modeler ver. 5.2. and for FDM technology it is applied the CatalystEX 4.4. For such kind of medical/anatomical models with small overall dimensions and small reliefs, was used the optimal parameters from stl. generation process and adequate parameters of $r p$. machines. Stl. meshes of various parts were decimated on 50000 to 200000 triangles to keep high quality reliefs of complex maxilla topology. The full maxillofacial area required about 150000-30000 triangles. For the biggest particular model in this case, it was 120000 triangles for external maximum dimensions of model $80 \mathrm{~mm} \times 60 \mathrm{~mm} \times 60 \mathrm{~mm}$. During stl. generation in ScanIP (Simpleware), gap tolerance between mesh and 3D model was defined between $0.05-0.1 \mathrm{~mm}$ [7] Checking and potential correction of stl. file were performed by Meshmixer as freeware solution
(Autodesk), but also Netfabb 5.1 was used where some complex issues in $3 \mathrm{~d}$ mesh were determined.

Prototyping parameters were, as follows:

1. FDM: layer resolutions: $0.1778 \mathrm{~mm}$ and $0.254 \mathrm{~mm}$, model interior: solid, support: smart

2. ProJet: HD mode - layer resolution: $0.032 \mathrm{~mm}$

In the following chapter, it will be discussed about the reached results based on presented methodology and analysed pre-processing parameters.

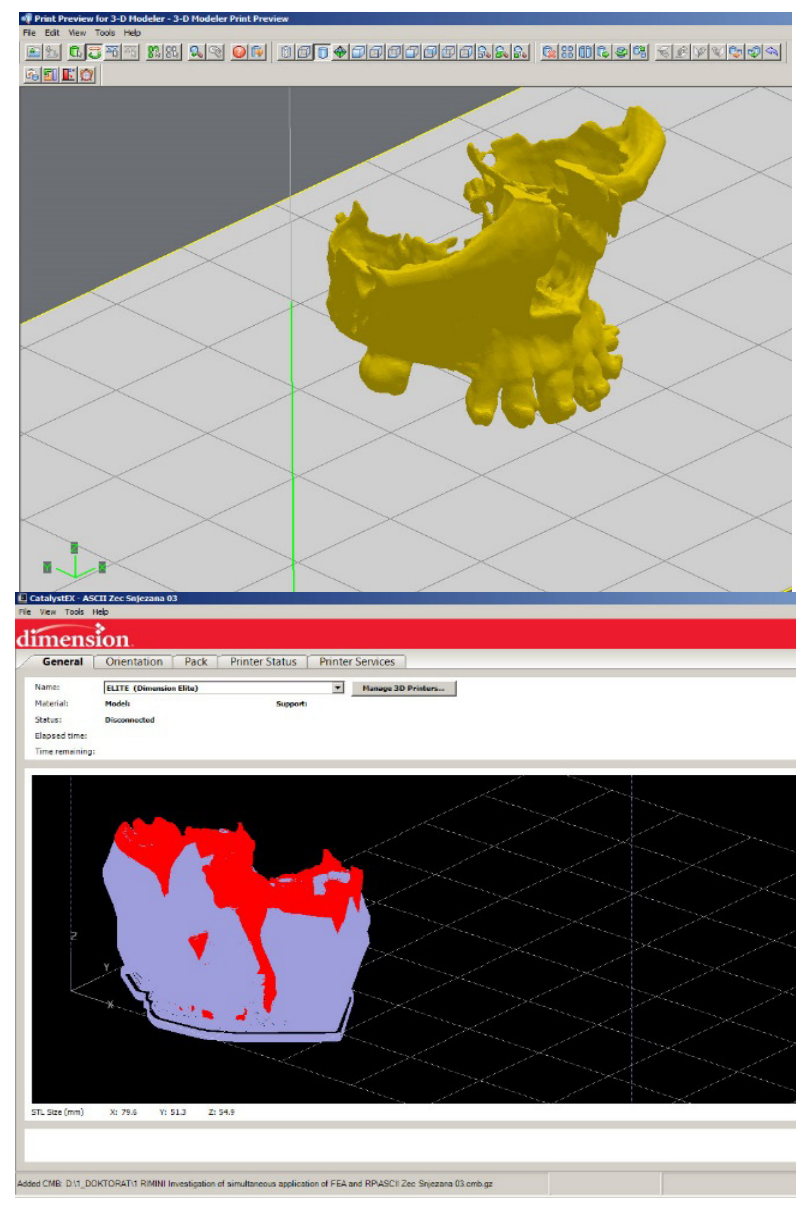

Figure 11: Software preprocessing for Multi-Jet (ProJet) printing technology and FDM technology

\section{THE RESULTS}

\subsection{FEA based results}

Figure 12 shows the stress distribution as simulated by MSC Patran/Nastran ' 12 , element size $0.4 \mathrm{~mm}$. It can be noticed, there is a complex stress condition on bending line with maximum stress, where there is a compound of torsion and bending at the same time. Since, the standard form of $0.8 \mathrm{~mm}$ is the biggest size in common fabricated set for mid-face for traumatology case, there are 2 solution variants. One solution is to make custom made titanium plates with thicker thickness $1.2 \mathrm{~mm}$. The second solution is to apply 4 standard titanium plates with $0.8 \mathrm{~mm}, 2$ on left and 2 on right face side.

Besides equivalent "Von Misses" stress testing related with yield strength, shear stress condition has been also tested because titanium and its alloys have lower shear strength. From the results in the table, it can be noticed, without such kind of FE simulation, it would be used the standard configuration for "trauma surgery 
case", which might not satisfied more complex stresses in osteotomy surgery preparation. So, this research makes certain contribution in clarifying similar surgery preparation issues beyond standard common solutions.
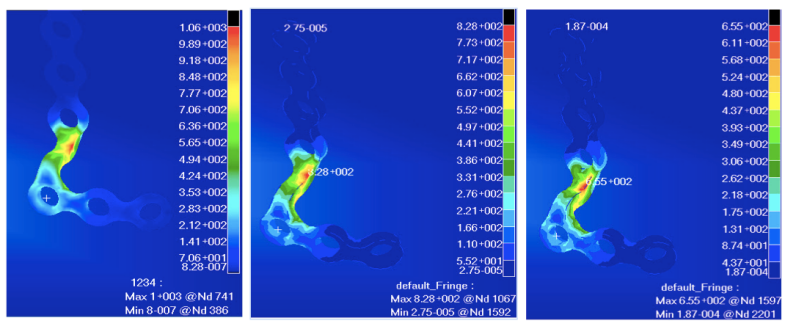

Figure 12: FE analysis of stresses for 3 thickness configurations a) $0.8 \mathrm{~mm}$; b) $1.0 \mathrm{~mm}$; c) $1.2 \mathrm{~mm}$

Table 1. Stress in titanium plates for different thickness

\begin{tabular}{|l|c|c|c|c|}
\hline \multirow{2}{*}{ Element } & \multicolumn{4}{|c|}{ Chemical composition (\%) } \\
\cline { 2 - 5 } & $\mathrm{SiO}_{2}$ & $\mathrm{Al}_{2} \mathrm{O}_{3}$ & $\mathrm{Fe}_{2} \mathrm{O}_{3}$ & $\mathrm{CaO}$ \\
\hline Cordierite (C) & 45.52 & 28.10 & 1.23 & 3.70 \\
\hline Talc (T) & 62.20 & 3.11 & 1.25 & 1.07 \\
\hline
\end{tabular}

\subsection{RP based results}

The model processing based on 2 technologies, FDM and MultiJet (ProJet) printing was tested. It was shown that RP models for surgery planning usually do not need very high resolution to get high surface quality. It is important to keep high dimensional accuracy and low time consumption for pre-processed computing and RP processing. In figure 13, it is presented the RP generated models. On the left side, it is the model before surgery, and on the right side, it is the model with simulation of cutting during surgery.

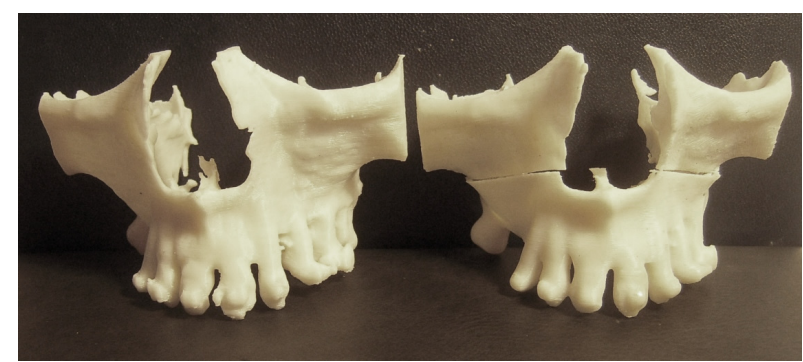

Figure 13: Generated models: model without cutting (left) and model with cutting and translation (right)

In the table 2, there are the results of time processing for various parameters and amount of copies. Also it is tested with more copies to represent the difference between FDM and Multi-Jet (MJP), their "pros and cons" for various cases. Since in this class of applications and mid-range investment in professional machines, these above-mentioned technologies are very frequent in use, it is important to select the optimal technology.

As the conclusion, it is recognized, in the case of less demanding of surface quality, but shorter processing time, better solution is FDM technology. Also, it can be noticed, the processing time increases with number of copies or number of models for one job. However, FDM has lower productivity for more packed the various or same models on working platform.
Table 2: Time processing for FDM and Multi-Jet (ProJet) printing of medical case model

\begin{tabular}{lccc}
\hline $\begin{array}{c}\text { Technology } \\
\text { type }\end{array}$ & $\begin{array}{c}\text { Number of } \\
\text { model copies }\end{array}$ & $\begin{array}{c}\text { Layer } \\
\text { resolution }\end{array}$ & $\begin{array}{c}\text { Processing } \\
\text { time (h:min) }\end{array}$ \\
\hline FDM & 1 & 0.1778 & $11: 45$ \\
\hline FDM & 2 & 0.1778 & $23: 31$ \\
\hline FDM & 1 & 0.254 & $7: 32$ \\
\hline FDM & 2 & 0.254 & $15: 04$ \\
\hline MJP & 1 & 0.032 & $12: 56$ \\
\hline MJP & 2 & 0.032 & $12: 56$ \\
\hline
\end{tabular}

MJP technology has only one primary parameter for processing speed, the height of model along z-axis. So, it has higher productivity rate for more copies or more models within one job. Also, it has significantly higher resolution, what can be useful for models, which requires higher surface quality, like in dentistry, prosthetics, jewellery etc.

\subsection{Surgery planning}

Finally, surgeons had digital and physical RP models, which could facilitate the surgery planning. Hence, the process flow presented in figure 2 , is validated as modern solution, it can assist to surgeons in selection of optimized plate's dimensions for osteotomy, and in preparing the most appropriate geometry of plates, which accurately follows the surface of maxilla model (figure 14).
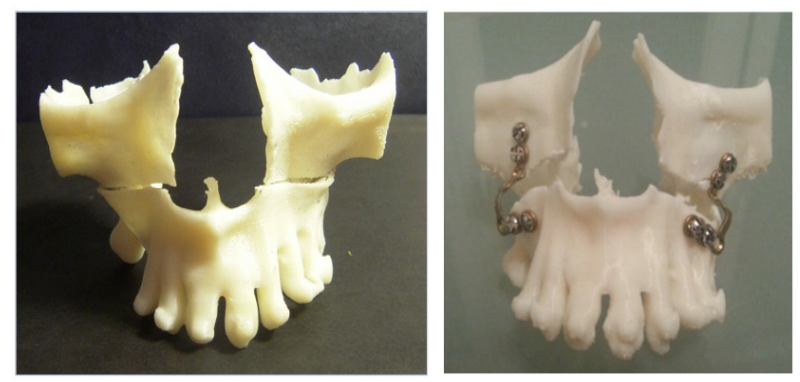

Figure 14: Assembled RP model with simulated cut (left) and prepared plates for osteotomy (right)

According to catalogued size and type of titanium plates primarily aimed for traumatology cases, plates were properly selected with bigger length, what provides more bending capacity and keeping adequate translation dimension for osteotomy. With special bending pliers, sterilized titanium plates were deformed to match conformed anatomic-like RP model's surface. On this way, the plates were ready to be implanted without long preparation, what significantly reduced surgery time.

\section{CONCLUSION}

In conclusion, the paper presents a new integrated engineering approach about osteotomy surgery planning with main focus on engineering tools and their synchronized applying. It aims to simplify the application of more sophisticated engineering tools like finite element analysis, hybrid modelling based on solid parametric, surface and mesh models together, and rapid prototyping [8]. In the future, it is inevitable to apply more up-to-date and the last innovative engineering 
tools, but to make enough "user-friendly" for medical applicants on regular daily base.

It was identified the decision model of proper selection of implanting plates for osteotomy cases, but the plates were primarily pre-designed for common traumatology applications. As shown, the osteotomy applications usually requires more complex deformed plates, and more complex stress conditions. Hence, the standard recommended plates in traumatology would be applied with higher size level and stronger for the osteotomy applications, if one observes the same anatomic location.

As for Cone Beam CT recording, it was recognized the imaging contrast issues, what required wider "threshold window" for saving more image information. It allowed the passing more levels and keeping more image contrast before adequate band pass image filtering of observed tissue. On the other side, it caused higher noise, which was reduced by other filters on $2 d$ imaging level and later in $3 d$ masking "voxelized" mesh.

On the other hand, it was pointed out the importance for simplification of FE analysis for validation, but good and robust enough for correct selecting decisions. Concerning RP technology and its pre-processing, it was advisable to use MultiJet Printing (PolyJet) for the cases with prototyping of more organic models on full packed working platform, since it represented a faster technology in that case, and it provided much higher surface quality with very good resolution. In practice, If, one needs only prototyping of one model with less demanding surface quality, it is recommendable FDM technology.

The future challenge for research is to improve FEA simulation with nonlinear approach within anatomy modelling, porosity modelling and including of nonlinear materials. It will comprise, so called, the greyscale modelling of anatomy sections from CT records, which is more accurate for realistic organic simulations.

\section{REFERENCES}

[1] Lantada, A. D. and Morgado P. L.: Rapid Prototyping for Biomedical Engineering: Current Capabilities and Challenges, Annu. Rev. Biomed. Eng. 2012. Vol. 14, 10.1146/annurev-bioeng071811-150112, pp. 73-96, 2012.

[2] Miracle, A.C. and Mukherji, S.K.: Conebeam CT of the Head and Neck, Part 1: Physical Principles, American Journal of Neuroradiology, Vol. 30, pp. 1088-1095, 2009.

[3] Miracle, A.C. and Mukherji, S.K.: Conebeam CT of the Head and Neck, Part 2: Clinical Applications, Vol. 30, pp. 1285-1292, 2009.

[4] Milisavljevic, S., et al.: Sternum Resection and Chest Wall Reconstruction with Metaacrilate Implant in Tuberculosis, Indian Journal of Surgery, Vol 75, pp. 257-260, 2013.

[5] Pileicikiene, G., Surna, A. Barauskas, R. Surna, R. and Basevicius A.: Finite element analysis of stresses in the maxillary and mandibular dental arches and TMJ articular discs during clenching into maximum intercuspation, anterior and unilateral posterior occlusion, Stomatologija, Baltic Dental and Maxillofacial Journal, Vol. 9, pp. 121128, 2007.

[6] Rues, S., Lenz, J., Schierle, H. P., Schindler, H. J., and Schweizerhof, K.: Simulation of the sinus floor elevation, Proceedings in Applied Mathematics and Mechanics, Vol. 4, pp. 368-369, 2004.

[7] Stanojevic, M. Sljivic, M. Plancak, M. and Djurdjevic, D.: Advanced investigation on rapid prototyping techniques in maxillofacial surgery and implanting preparation, Journal for Technology of Plasticity, Vol. 39, No. 1, 2014.

[8] Farias, T. P., Dias, F. L. Sousa1, B. A., Galvao, M. S., Bispo, D. and Carolina, A.: Prototyping: Major Advance in Surgical Planning and Customizing Prostheses in Patients with Bone Tumors of the Head and Neck, International Journal of Clinical Medicine, Vol. 40. pp. 1-7, 2013.

\section{ИМПЛЕМЕНТАЦИЈА МКЕ МЕТОДЕ И РАПИД ПРОТОТАЈПИНГА У МАКСИЛО- ФАЦИЈАЛНОЈ ХИРУРГИЈИ}

\section{М. Шљивић, М. Станојевић, Д. Ђурђевић, Н. Грујовић, А. Павловић}

Овај рад истражује могућност имплементације КЕ симулације и брзе технике прототипова титан импланта у максилофацијалној хирургији случаја остеотомије. Регија вилице је снимљена коришћењем Cone Beam CT високе резолуције и са оптималним зрачењем. Затим, следе реконструкција медицинске слике у 3D воштаном моделу.

Овај модел је претворен, у ctl. модел површина за брзу израду прототипова за CAD моделирање и реализацију мреже коначних елемената за потребе симулација водећи рачуна о димензијама и запремини модела. Ctl. мрежа елемената је унапређена за увез у CAD софтвер, као почетна 3D структура, која је коришћена за параметарски дизајн релизације импланта. Пошто је остеотомија коначна апликација, симулирано је резање и померање вилице за правилну корекцију путем дигиталних прототипова. Затим, фиксирања тачака за померену вилицу су одређена хируршки да би обезбедила стабилну везу између вијака и вилице. Примењени имплантат је дат у почетној стандардној равној конфигурацији.

Равна конфигурација имплантаје адаптирана комплексним 3D савијањем у CAD софтверу да би се прилагодила површини максилофарциалне анатомије. Коришћењем КЕ симулације у МСC Patran/Nastran, изврњена је анализа напона импланта са различитим конфигурацијама дебљине и 3D савијања, што омогућује оптимално решење имплант модела са најбољим димензијама.

Оптимизован модел импланта и одговарајући модел тела су претворени у физичке моделе. RP модел вилице је обрађен да би пружио адекватно позиционирање имплантата према дигиталном прототипу. Овакав приступ омогућава израду 
комплексних облика импланта, који би требало да буду у високом степену усаглашени са анатомијом површине вилице. Да би се потврдиа могућност примене у пракси, све предходно наведено је примењено и тестирано у конкретном случају операције максилофациалне остеотомије. 